\title{
INFLUENCE OF DIAZEPAM ON THE EMERGENCE REACTIONS FOLLOWING KETAMINE ANAESTHESIA
}

\author{
L. LoIr, M.B., B.S., F.F.A.R.C.S., L. SINGER, M.B., B.S., M. MORGAN, M.B., B.S., F.F.A.A.C.S., \\ AND P. H. MoORE, F.F.A.R.C.S.
}

ONE OF THE UNDESIFABLE FEATURES of ketamine anaesthesia is that it is frequently followed in the recovery period by states of vivid dreaming, which may be accompanied by vocalization and movement. These dreams may be remembered by the patient, and range from the pleasurable to the terrifying. For the purposes of this paper we will refer to these as emergence reactions.

In a previous communication ${ }^{1}$ we reported our experiences with ketamine as the sole anaesthetic agent in 140 cases, in which the overall incidence of emergence reactions was 10 per cent. However, in that series there were no emergence reactions in children. Thus, 12 per cent of patients over the age of 14 years had unpleasant frightening dreams which they could recall. The lowest incidence of emergence reactions occurred in those patients in whom pre-operative medication consisted of either papaveretum and hyoscine or droperidol and hyoscine. It was suggested to $u^{2}$ that the intravenous administration of a small dose of diazepam at the end of operation might reduce the incidence of these reactions. The present study was designed to investigate this.

\section{Method}

Any adult patient scheduled for minor surgery was included in the trial provided that there was no contra-indication to ketamine anaesthesia, such as hypertension, cardiac decompensation, a history of cerebro-vascular disease or of psychiatric disorder. Pre-operative medication was allocated randomly on the basis of the patient's central registry number, and consisted of either papaveretum ( 10 or 20 $\mathrm{mg}$ ) with hyoscine ( 0.2 or $0.4 \mathrm{mg}$ ), or droperidol ( 5 or $10 \mathrm{mg}$ ) with hyoscine $(0.2$ or $0.4 \mathrm{mg}$ ). Patients weighing less than $60 \mathrm{~kg}$ were given the smaller dose.

The induction dose of ketamine was $2.0 \mathrm{mg} / \mathrm{kg}$ given intravenously over a period of 45-60 seconds. Increments of half the induction dose were given when needed. All patients were allowed to breathe room air, and no other agents were given. At the end of the operation we ensured that all patients were fully under the influence of ketamine until all dressings, lifting and turning had been completed. Therefore more ketamine was often given even though it was judged not to be necessary for the surgery itself. Before removing the patient from the table diazepam $5 \mathrm{mg}$ was given intravenously, and this group of patients constituted the test group.

During recovery, all patients were observed but not stimulated in any way. Pulse rates and blood pressures were not taken, and no attempt was made to determine

Department of Anaesthetics, Royal Postgraduate Medical School, Hammersmith Hospital, DuCane Road, London, W12 OHS, and Prince of Wales' Fospital, Tottenham, London, N.15. 
the recovery time. Each patient was visited by one of the investigators on the day following the operation.

The results obtained were compared with those of the 85 patients in the previous series who had received the same pre-operative medication. These patients had been treated in exactly the same way, but no diazepam had been given, and they constituted the control group.

\section{Results}

One hundred anaesthetics were administered to 98 patients, two patients receiving ketamine on two separate occasions. Of these patients, 42 received droperidol and hyoscine as pre-operative medication, and 58 papaveretum and hyoscine. Details of these patients, and those from the original series (who did not receive diazepam) are shown in Table $\mathrm{I}$. The number of emergence reactions in relation to pre-operative medication in both groups is shown in Table II, and in relation to the operations performed in Table III.

The incidence of emergence reactions in those who received diazepam was 11 per cent, and in the control group it was 9.4 per cent. A chi-square test using $2 \times 2$ contingency table method of statistical analysis showed no significant difference in the frequency of the emergence reactions in the two groups, nor were there any differences between the premedication groups.

\section{Discussion}

Ideally, the control and test groups should have run concurrently rather than consecutively, but the patients had comparable operations and were treated identically apart from the administration of diazepam. It will be seen that there was no significant difference between the mean ages, but there was a significant difference between their mean weights (Table I) since there were more males in the test group. The ketamine was given on a weight basis so that this is unlikely to have introduced bias.

The incidence of emergence reactions in both groups is lower than that reported by Dundee et al. (1970), ${ }^{3}$ Bovill et al. (1971) ${ }^{4}$ and Galloon (1971). ${ }^{5}$ Bovill et al.4 stated that both opiate-hyoscine and droperidol containing premedication reduced

TABLE I

Details of Patients in Control and Test Groups

\begin{tabular}{|c|c|c|c|c|}
\hline & \multicolumn{2}{|c|}{ No Diazepam } & \multicolumn{2}{|c|}{ Diazepam } \\
\hline & Number & $\%$ & Number & $\%$ \\
\hline $\begin{array}{l}\text { Number of patients } \\
\text { Number of anaesthetics } \\
\text { Males } \\
\text { Females } \\
\text { Droperidol and byoscine } \\
\text { Papaveretum and hyoseine }\end{array}$ & $\begin{array}{l}85 \\
85 \\
17 \\
68 \\
36 \\
49\end{array}$ & $\begin{array}{l}20 \\
80 \\
42.5 \\
57.5\end{array}$ & $\begin{array}{r}98 \\
100 \\
30 \\
70 \\
42 \\
58\end{array}$ & $\begin{array}{l}30 \\
70 \\
42 \\
58\end{array}$ \\
\hline $\begin{array}{l}\text { Mean age }(y r) \pm S . D \\
\text { Mean weight }(\mathrm{kg})\end{array}$ & \multicolumn{2}{|c|}{$\begin{array}{l}35.09 \pm 14.4 \\
60.67 \pm 13.6\end{array}$} & $\begin{array}{l}39.13 \pm 15.85 \\
65.72 \pm 13.9\end{array}$ & $P=0.014$ \\
\hline
\end{tabular}


TABLE II

Iacebence of Emergence Reactions (E.R.) in Relation to Pre-operative Medication

\begin{tabular}{lccccccrr}
\hline & \multicolumn{3}{c}{ No diazepam } & & \multicolumn{3}{c}{ Diazepam } \\
\cline { 2 - 4 } \cline { 6 - 8 } Pre-operative medication & Number & E.R. & $\%$ & & Number & E.R. & $\%$ \\
\hline Droperidol and hyoscine & 36 & 3 & 8.3 & & 42 & 3 & 7.1 \\
Papaveretum and hyoscine & 49 & 5 & 10.2 & & 58 & 8 & 13.8 \\
Torals & 85 & 8 & 9.4 & & 100 & 11 & 11.0 \\
\hline
\end{tabular}

TABLE III

Incibence of Emergence Reactions (E.R.) in Relation to Operation Groups

\begin{tabular}{|c|c|c|c|c|c|c|}
\hline \multirow[b]{2}{*}{ Type of operation } & \multicolumn{3}{|c|}{ No diazepam } & \multicolumn{3}{|c|}{ Diazepam } \\
\hline & Number & $\begin{array}{c}\text { Number } \\
\text { E.R. }\end{array}$ & $\%$ & Number & $\begin{array}{c}\text { Number } \\
\text { E.R. }\end{array}$ & $\%$ \\
\hline Gynaecological & 55 & 4 & 7.3 & 54 & 4 & 7.4 \\
\hline General surgery & 12 & 1 & 8.3 & 13 & 1 & .7 .7 \\
\hline Orthopaedic & 10 & 1 & 10 & 19 & 4 & 21 \\
\hline Genito-urinary & 8 & 2 & 25 & 14 & 2 & 14.2 \\
\hline Totals & 85 & 8 & 9.4 & 100 & 11 & 11 \\
\hline
\end{tabular}

frequency of emergence delirium. They found that although droperidol, $5 \mathrm{mg}$ given intravenously towards the end of the operation, reduced the frequency of emergence upset, it had little effect on the occurrence of recalled dreams after ketamine. When diazepam was substituted for droperidol, the frequency of emergence upset was increased, but that of dreaming decreased. However, unpleasant dreams were still recalled in 15 per cent. Similarly, Galloon $(1971)^{5}$ gave diazepam $2.5 \mathrm{mg}$ intravenously to 51 patients anaesthetized with ketamine and premedicated with pantapon and atropine, with an incidence of reported unpleasant dreams of 15.7 per cent.

Corssen, Miyasaka and Domino $(1968)^{8}$ noted that the undesirable psychomotor activity during early recovery was associated with premature efforts on the part of the recovery room staff to awaken the patients. They stated that any attempts to awaken patients who were unable to orientate themselves could lead to a chain of anxiety reactions which could result in psychomotor activity and irrational behaviour. When these authors avoided any form of stimulation of the patient during recovery, emergence reactions were virtually absent. We therefore tried to ensure that all patients were fully under the influence of ketamine until they were in the recovery room, and that any stimulation was avoided during recovery. The patients were not disturbed for pulse rate and blood pressure measurement, and no attempt was made to determine the recovery time by commanding them to open their eyes, etc. Although 11 per cent of the patients presented here, and 9.4 per cent of the 85 patients from the previous series had unpleasant, frightening dreams, which we consider to be unacceptably high, none showed any delirium or irrational behaviour during recovery. 
The use of nitrous oxide as a supplement to ketamine anaesthesia for short procedures deserves some examination. Under such circumstances, one could envisage that recovery from the initial dose of ketamine would begin, but that the patient would be kept unconscious by nitrous oxide. At the end of the operation the nitrous oxide would be discontinued, with rapid recovery of consciousness, and the patient would be moved from the operating table to a trolley or bed, turned on his side and wheeled into the recovery area at the time when stimulation could lead to anxiety reactions. Support for this view is obtained from the observation in this and the previous series that the incidence of emergence reactions was the same in gynaecological patients anaesthetized with ketamine as the sole agent regardless of the type of pre-operative medication, whereas in the initial series reported by Dundee et al. (1970) ${ }^{3}$ using supplementary nitrous oxide, half of the patients had dreams, and in two thirds of these the dreams were of an unpleasant nature. Thirty-three per cent of their patients were disturbed to some extent during recovery, this being severe in 50 per cent. Galloon $(1971)^{5}$ reported an incidence of unpleasant dreams of 12.7 per cent in 55 patients premedicated with pantapon and hyoscine and anaesthetized with ketamine as sole agent, but 22 per cent when 50 patients were anaesthetized with ketamine supplemented with nitrous oxide.

Ketamine has several valuable features which have been documented previously, but in spite of these the incidence of emergence reactions is unacceptably high. Unless they can be reduced by some simple means, the use of ketamine as an anaesthetic agent ought to be limited to circumstances where the peculiar advantages of ketamine can be judged to outweigh this disadvantage e.g. surgery under adverse circumstances such as at the site of major accidents, neuroradiological investigations and radiotherapy in children, repeated burns dressings.

\section{SUMMARY}

One hundred patients anaesthetized with ketamine as the sole agent for minor surgical procedures, were given diazepam $5 \mathrm{mg}$ intravenously at the end of the procedure. The incidence of emergence reactions was the same as in a previous series of 85 patients who had received the same pre-operative medication and underwent similar operative procedures but had no diazepam.

\section{RÉSUMÉ}

Cent malades anesthésiés à la ketamine seule, pour des opérations mineures, ont reçu par voie intra-veineuse, $5 \mathrm{mg}$ de diazépam à la fin de l'opération. La fréquence des réactions au réveil a été la mếme que celle qu'on avait observée lors d'une série de 85 cas qui, dans des circonstances identiques, n'avaient pas reçu de diazépam.

\section{ACKNOWLEDGMENT}

We would like to thank Miss J. Green for secretarial assistance. 


\section{REFERENCES}

1. Moncas, M., LoH, L., Singer, L., \& Moone, P.H. Ketamine as the sole anaesthetic agent for minor surgical procedures. Anaesthesia, 26, 158 (1971).

2. Danchin, J. Personal communication (1970).

3. Dunore, J.W., Bovile, J., KNox, J.W.D., Clarex, R.S.J., Black, G.W., Love, S.H.S., Moome, J., Elltotr, J., Pandi, S.K., \& CopPel, D.L. Ketamine as an induction agent in anaesthetics. Lancet, 1,1370 (1970).

4. Bovilu, J.G., Guarke, R.S.J., Dundee, J.W., Pandrt, S.K., Moore, J. Clinical studies of induction agents. XXXVIII: Effect of premedicants and supplements on ketamine anaesthesia. Brit. ]. Anaesth., 43, 600 (1971).

5. Galloon, S., Ketamine for dilatation and curettage. Canad. Anaes. Soc. J., 18, 600 (1971).

6. Conssen, G., Mryasaka, M., Domno, E.F. Changing concepts in pain control during surgery: Dissociative anesthesia with CI-581. A progress report. Anesth. Analg. Curr. Res., 47, 746 (1968). 